\title{
Effect of Tax Planning on Firm Value of Manufacturing Firms Listed At the Nairobi Securities Exchange
}

\author{
Gedion M. Isaac Mwaluku
}

\begin{abstract}
This study examined the effect of tax planning on firm value of manufacturing firms listed at the Nairobi Securities Exchange for a ten-year period 2010 to 2019. Specifically, the study sought to: evaluate the influence of assets' tangibility on firm value of manufacturing firms listed at the Nairobi Securities Exchange; determine the influence of leverage on firm value of manufacturing firms listed at the Nairobi Securities Exchange; and establish the effect of effective tax rate on firm value of manufacturing firms listed at the Nairobi Securities Exchange.

The study was anchored on three theories: the pecking order theory; the agency theory and the political power theory. The study adopted longitudinal research survey and employed panel least squares analysis. The population of this study was all the 13 manufacturing companies listed on the manufacturing, construction and allied sectors of the Nairobi Securities Exchange as of December 2020. Due to the small number of firms, census technique was adopted and hence sampling was be required.

Findings of the study indicated that asset tangibility had a positive, though statistically insignificant effect on firm value. Leverage was found to have a positive and a statistically significant relationship with firm value. Furthermore, results of the study indicated that effective tax rate had a positive and statistically significant influence on firm value.
\end{abstract}

\section{KEYWORDS: Asset Tangibility, Effective Tax Rate, Firm Value, Tax Planning, Nairobi Securities Exchange}

\section{CHAPTER ONE}

\section{INTRODUCTION}

\subsection{Background to the Study}

Tax planning is plays an indispensable part in supporting corporates' strategic decisions and value enhancing activities (Mgammal, 2020). The tax expenses of a business can sometimes be excessive often burdening companies' profitability and value. Nevertheless, businesses can reorganise their activities and operations in such a way as to enhance tax benefits (Feng, Habib, \& Tian, 2019). The main goal of tax planning is this reducing the overall tax liability. Further, according to Christina and Alexander, (2019) tax planning ensures that funds forming taxable sources are utilised in productive investment activities thus aiding business growth. While tax planning activities allows corporates to reduce their tax liability by making optimal use of tax allowable deductions, the same must be made within the confines of law to minimise, or completely eliminate tax related litigation (Kiesewetter \& Manthey, 2017). According to Christina (2019), tax planning opportunities for corporations exists irrespective of their size or the jurisdiction of their operations. Tax planning activities are reflected on the firm's financial reports. Due to the close association between tax, accounting and finance, well planned corporate tax results to financially healthy financial statements.
Firm value is a critical constituent adopted to gauge managers' performance in most corporate entities (Omesi \& Appah, 2021). In their capacity as shareholder's representatives, managers have an obligation of optimizing and maximizing value. According to Izevbekhai and Odion (2018), firm value as represented by the assets it owns equally describes the shareholders wealth. Kirkpatrick and Radicic (2020) opinion that tax planning is relevant to firm value.

The manufacturing sector in Kenya plays an important role in the country's economic development and contributes not only to national output but also to creation of employment opportunities (KNBS, 2020). The Kenyan government expects the sector to contribute 15 percent to the Gross Domestic Product (GDP) by the year 2022. However, this contribution has experienced declined growth from 9.4 percent in 2015 to 7.5 percent in 2019. According to the economic survey report by the KNBS (2020), manufacturing sector grew in value by 3.2 percent in 2019 a significant drop from 4.3 growth rate attained in 2018 . The performance of the manufacturing sector is influenced by among others high cost of doing business, excessive taxation including double taxation (Kenya Association of Manufacturers, 2021).To address this challenge, various tax incentives have been advanced to the sector by the government of Kenya. However, the impact of the taxation measures on firm value 
of manufacturing studies have not been conclusively examined.

\subsubsection{Tax Planning}

Corporate tax planning involves several methods aimed at reduction of expenses for every aspect of business tax. Making full use of local tax benefits is one of the most straightforward ways of tax planning (Mgammal, 2020). Though Kenya has a relatively higher tax rate compared to other countries in Africa, there are a number of investment allowances that act as tax incentives to manufacturing firms. Examples includes, investment deduction, wear and tear allowance and industrial building allowance all jointly referred to as capital expenditure allowance are some of the tax incentives available to manufacturers in Kenya (Government of Kenya, 2020). Extant literature has adopted capital expenditure as a proxy for tax planning. For instance, Bhagiawan and Mukhlasin (2020) employed capital expenditure as a proxy for tax planning and examined its influence on firm value among manufacturing firms listed in Indonesia. The study adopted total assets as the operational indicator of capital expenditure. However, Vu and Le (2021), while examining the effect tax planning had on firm value of non-financial firms in Vietnam used tangible assets as the operational indicator of the independent variable.

Financial leverage is the other indicator that have been used in empirical studies to explain the relationship between tax planning and firm value. In Nigeria, Omesi and Appah (2021) observed that firms whose debt was higher compared to equity were more efficient in lowering amounts charged as tax. The opined that highly leveraged firms were able to lower the tax burden as interest payments on debt are tax deductible. Despite the unanimity in usage of leverage as a tax planning tool, there is no consensus on its measure. Omesi and Appah (2021) operationalised leverage as total long-term debt as a ratio of total assets. However, Oeta, Kiai and Muchiri (2019) while investigating the influence of tax planning on financial performance of Kenyan firms, operationalised financial leverage as debt to equity ratio.

The extant literature reviewed have affirmed that effective tax rate, as a proxy of tax planning is associated with firm value (Feng et al., 2019; Kiesewetter \& Manthey, 2017; Mgammal, 2020; Omesi \& Appah, 2021). Effective tax rate has been used in prior studies as a reflection of a tax planning measure that reduces tax liability without necessarily reducing accounting income (Kirkpatrick \& Radicic, 2020). According to Omesi and Appah (2021), effective tax rate assesses the tax planning ability of the firm by evaluating the actual corporate tax burden and reveals the managers ability to minimise tax expense by generating permanent tax saving as well as temporal tax savings through deferred corporate tax. The concept of effective tax rate is defined differently in different studies. For instance, Bhagiawan and Mukhlasin (2020) define effective tax rate as ratio of aggregate of all forms of tax paid to taxable income. On their part, Feng et al. (2019), used the difference between total income tax expense and deferred tax expense divided profit before tax. Omesi and Appah (2021) operationalised effective tax rate as the percentage of total tax cash expense and before tax income. Similarly, Kirkpatrick and Radicic (2020) measured effective tax rate as the quotient of tax expense in the income statement and before tax profit as recognised in the audited financial statements.

\subsubsection{Firm Value}

The two major goals of a firm are maximization of financial performance and value enhancement. While attainment of superior financial performance is a more short-term goal, firm value on the other hand, focuses more on long term sustainability of the company (Vu \& Le, 2021). Firm value, which companies are determined to raise, is seen as the main indicator when it comes to evaluating the performance of a business entity (Ni, Cheng, \& Huang, 2020). Christina (2019) holds that investable firms significantly increases their market values as well as tangible investment. Thus, firm value is regarded as a key consideration to both firms and their shareholders. According to Kirkpatrick and Radicic (2020), firm value describes the wealth of the shareholders as a high value firm is seen as profitable from the stakeholders view point. Investors also view investable opportunities in companies through its firms' value and this is related to the price of its listed securities.

Despite proliferation of literature on firm value, there lacks consensus on measures of firm value. While some scholars argue that accounting-based measures are superior, others are of the view that stock market measures are superior. As noted in the foregoing, there are different methods through which firm value can be meted. Among the measures of firm value are the book value of the firm, otherwise referred to as the net worth of the firm. However, the use of book value as a measure of firm value suffers from certain defects arising from various methods of treating accounting data (Galpin, 2020). Furthermore, the value of a firm can also be measured using market values. Market value, otherwise defined as market capitalisation is computed as the product of outstanding shares and market price at a point in time. Companies with higher market capitalisation are considered to have a higher firm value (Oeta et al., 2019). Tobin's Q has also been adopted a measure of firm value in literature (Bhagiawan \& Mukhlasin, 2020; Kiesewetter \& Manthey, 2017; Nafti, Kateb, \& Masghouni, 2020; Omesi \& Appah, 2021). The Tobin's Q ratio measures firm value as the quotient of market capitalisation and its assets replacement cost. In the present study, firm value is indicated by the Tobin's Q ratio operationalised in line with Omesi and Appah (2021) who points out that the ratio indicated a market estimation of the firm value in relations to its return on investment from the perpective of investors. 


\subsubsection{Manufacturing Firms in Kenya}

The Nairobi Securities Exchange (NSE) has a count of 61 firms that it has listed. These fall into 11 sectors. The various sectors are agricultural, commercial and services, telecommunication and technology, automobiles and accessories, banking, insurance, investment, manufacturing and allied, construction and allied, energy and petroleum, and growth enterprise market segment. The other two sectors are fixed income securities market segment which lists preference shares and bonds (Capital Markets Authority, 2021). The listed firms perform differently in terms of their profitability as well as share values. In terms of their tax management practices, some pay larger taxes than others and this call for an examination of their tax management practices. These varied share performance and tax payments calls for an examination of how these two are related. The tax perspectives for manufacturing firms are broader in the value chain creation since a wider range of chances to succumb to taxes presents itself from raw materials growth/sourcing, transformation, packaging, distribution, selling and reporting. The research proposes to concentrate on firms listed under manufacturing and allied and construction and allied sectors out of which ( 9 companies) data is utilised in this study (panel data). These companies have varied ownership structures and are generally in manufacturing concerns. Some are foreign owned while others are purely domestic while others have a mixture of both. Some are state owned with the Government of Kenya having majority shares. They all have attachment in operations, assets base and outputs in the area of manufacturing or construction.

\subsection{Statement of the Problem}

The manufacturing sector is a major contributor to the economic growth in any country (Mogote, Kiai, \& Muchiri, 2019). According to Kenya Association of Manufacturers, (2021), the manufacturing industry is the engine that drives the economy. In the majority of developing nations, such as Kenya, great emphasis is placed on manufacturing firms to allow for the realization of the country's economic growth objectives. Kenya has made strides in its effort to industrialise as directed by the objectives set out in Vision 2030 blue print and big four agenda (KNBS, 2020). Further, the sector has been provisioned with incentives aimed at encouraging investments in the industry both from local investors and also through foreign direct investments. Moreover, growth of firm value and profit maximization are important goals that firms across different sectors seek to attain.

Despite the government of Kenya's efforts to promote the manufacturing sector, a number of Manufacturing firms listed at the Nairobi Securities Exchange have recorded declining performance and thus destroyed value. For instance, over the past five years two manufacturing firms, Mumias Sugar Plc and ARM Cement Plc have has a run of poor performance resulting to their suspension from the bourse (Capital Markets
Authority, 2021). Further, though firm value of listed firms as measured by market capitalization increased by 21 percent in 2019 compared to 2018,85 percent of the stated value was attributed to just ten companies (Capital Markets Authority, 2021). However, of the ten, only one, East African Breweries Plc was in the manufacturing sector. This raises serious concerns on value creation in the sector. Furthermore, the sector is considered as a pillar to sustained economic growth in Kenya and the worrying performance compels this study to establish the effect of tax planning on firm value of manufacturing companies quoted at the Nairobi Securities Exchange.

Tax planning have been thought to be a critical investment decision due to its ability to bring down the taxation burden that impacts significantly on firm value. However, as tax planning has cost implication, its impact on value of the firm can either be positive or negative. Empirical review of literature established that studies that have examined the relationship between tax planning and firm value remain fragmented and inconclusive and there still remains unresolved issues. First, while some have reported that tax planning generally enhances firms' value (Nafti et al., 2020; $\mathrm{Vu} \& \mathrm{Le}, 2021$ ), others found that tax planning is unrelated to firm value (Mogote et al., 2019; Oeta et al., 2019) there is need to establish if tax planning influences firm value or otherwise. This notwithstanding, the studies on tax planning have focussed on the influence of single variable such as effective tax rate (Assidi et al., 2016; Izevbekhai \& Odion, 2018) or asset tangibility (Mogote et al., 2019) on firm value. Yet no firm uses just a single option of tax planning available. This has created conceptual gaps that need to be filled. It is necessary therefore, to establish the combined effect of the various forms of tax planning on firm value.

Contextual and methodological gaps also exist in the reviewed extant literature. Contextually, few studies have focussed on the Kenyan context. For instance, $\mathrm{Vu}$ and Le (2021) study was in the context of listed non-financial firms in Vietnam, while Christina and Alexander (2019) focused on manufacturing firms listed in the Indonesian stock exchange. These findings may not be inferred on the Kenya's manufacturing sector. Methodologically, few studies are longitudinal in nature, yet the effects of tax planning decisions on firm value are likely to be felt over a lenthy period of time. This study therefore sought to fill the conceptual, contextual and methodoligical gaps identified by investigating the influence of tax planning on firm value of listed manufacturing firms in Kenya.

\subsection{Objectives of the Study 1.3.1 General Objective}

The broad objective of this study was to examine the effect of tax planning on firm value of manufacturing firms listed at the Nairobi Securities Exchange. 


\subsubsection{Specific Objectives}

The specific objectives of the study were to:

i. Evaluate the influence of assets' tangibility on firm value of manufacturing firms listed at the Nairobi Securities Exchange.

ii. Determine the influence of leverage on firm value of manufacturing firms listed at the Nairobi Securities Exchange.

iii. Establish the effect of effective tax rate on firm value of manufacturing firms listed at the Nairobi Securities Exchange.

\subsection{Research Hypotheses}

Based on the study objectives, the following hypotheses were developed and tested at 95 percent level of confidence.

$\mathrm{H}_{01}$ : Assets' tangibility has no significant influence on firm value of manufacturing firms listed at the Nairobi Securities Exchange in Kenya

$\mathrm{H}_{02}$ : Leverage have no significant association with firm value of manufacturing firms listed at the Nairobi Securities Exchange in Kenya.

$\mathrm{H}_{03}$ : Effective tax rate does not significantly influence on firm value of manufacturing firms listed in the Nairobi Securities Exchange in Kenya.

\subsection{Justification of the Study}

Tax affects various stakeholders in any business concern. Its's a critical part of the fiscal policy in place to raise funds for the government which in turn finances common good for all its populace within its jurisdiction. This proposal seeks to demystify tax planning and shed more light on various arrangements that seem obvious but are critical to influence overall performances of firms and tax savings.

While the government is expecting its share, so are the owners, clients and employees. This balance especially in manufacturing concerns is highly called for hence a justification of this proposal as it seeks to breakdown these variables that are of essence in tax planning and ending value of the firms. Levin and Widell (2007) compared the tax evasion in Kenya and Tanzania while Kamau, Mutiso, and Ngui (2012) described tax avoidance and evasion as one of the major factors influencing creative accounting practice in Kenya. These local studies done have not yet pointed out specifically on manufacturing sector and also the relation of value to attributes of capital deductions, leveraging level and offshore arrangements. This gap is thus a main focus in this study.

\subsection{Scope of the study}

The study proposed to highlight on tax planning and value of manufacturing firms listed at NSE. They are nine currently (see appendix 1). The tax perspectives for manufacturing firms are broader in the value chain creation since a wider range of chances to succumb to taxes presents itself from raw materials growth/sourcing, transformation, packaging, distribution, selling, after sale service and reporting returns to stakeholders after taxation effect.

\section{CHAPTER TWO LITERATURE REVIEW}

\subsection{Introduction}

In this chapter, the research will explore literature related to the effect of tax planning on firm value. It will also consider the theoretical and empirical evidence on this subject. Finally, this chapter will provide an exposition of the research gap and the summary of the chapter in general.

\subsection{Theoretical Review}

Under this section, the study analyses three major theories relevant to tax planning, namely, the pecking order theory, the agency theory and the political power theory as key source of inspiration to tackle the variables in our study.

\subsubsection{Pecking Order Theory}

Proponents of this theory, assert that with asymmetric information as managers know more about their company's prospects, risks and value than outside investors. Stewart C. Myers and Nicolas Majluf in 1984 modified the earlier version of Donaldson (1961) by asserting that companies prioritize their sources of financing according to the cost of financing, preferring to raise equity as a financing means of last resort. Asymmetric information affects the choice between internal and external financing and between the issue of debt or equity. There thus exists a pecking order for the financing of new projects. Asymmetric information favours the issue of debt over equity as the issue of debt signals the board's confidence that an investment is profitable and that the current stock price is undervalued (were stock price overvalued, the issue of equity would be favoured). The issue of equity would signal a lack of confidence in the board and that they feel the share price is over-valued. An issue of equity would therefore lead to a drop in share price.

Finally, tests of the pecking order theory have not been able to show that it is of first-order importance in determining a firm's capital structure. Brealey RA, Myers SC, and Allen F (2008) show, among other things, that Pecking Order theory fails where it should hold, namely for small firms where information asymmetry is presumably an important problem. The approach in balancing the source of funds amounts to tax planning in that they check the one with huge tax savings as opposed to getting returns that will attract full band tax rate. This applies to the delicate balance of tax planning in the seeking of whom should power of decision making go to and the saving reward.

\subsubsection{The Agency theory}

According to agency perspective of tax, the problem that needs to be solved by investors is simply managerial shirking. Avoidance also considers another form of the agency problem: managerial opportunism or resource diversion 
(Desai and Dharmapala, 2009b). Tax avoidance looks at varied dimensions of the agency tension between managers and investors hence fully applicable to this study.

Desai and Dharmapala (2006) contend that complex tax avoidance transactions can provide management with the tools, masks, and justifications for opportunistic managerial behaviours, such as earnings manipulations, related party transactions, and other resource-diverting activities. In other words, tax avoidance and managerial diversion can be complementary. Using a case analysis, Desai (2005) provides detailed evidence on how these opportunistic managerial behaviours can be facilitated by tax avoidance. This agency view of tax avoidance is attracting increasing attention in the literature (Hanlon and Heitzman, 2009). For example, Desai and Dharmapala (2006) show that strengthened equity incentives actually decrease tax avoidance for firms with weaker governance, consistent with the view that tax avoidance facilitates managerial diversion. Chen et al. (2010) find that family firms are less tax aggressive than their nonfamily counterparts. The authors conclude that family owners appear to forgo tax benefits to avoid the non-tax cost of a potential price discount arising from minority shareholders' concern about family rent seeking masked by tax avoidance activities.

There is more examining done on the stock market consequences of tax avoidance activities under the agency perspective. Desai and Dharmapala (2009a) find no relation between tax avoidance and firm value; however, they do find a positive relation between the two for firms with high institutional ownership. Their finding suggests that tax avoidance has a net benefit in an environment in which monitoring and control effectively constrain managerial opportunism afforded by tax avoidance activities. Hanlon and Slemrod (2009) examine the market reaction to news about a firm's involvement in tax shelters. The authors find a negative market reaction to tax shelter disclosure, suggesting that investors are concerned about the possibility that tax shelters are intertwined with managerial diversion and performance manipulation.

Furthermore, the authors find that the negative reaction is less pronounced for firms with stronger governance; however, this result seems to be sensitive to how governance is empirically measured.

\subsubsection{Political Power Theory}

This theory of political power (Siegfried, 1972) predict that large companies face lower effective tax rate. From a political economy perspective, tax burden could be linked to company size. In some studies, it was found that small businesses may suffer in terms of average cost of capital because they cannot benefit from economies of scale. On the other hand, large firms may have more political power to negotiate their tax burden, particularly through trade unions, because they are more mobile and have a greater impact on employment when moving or leaving a market. On the other hand, political cost theory (Watts and Zimmerman, 1978) argue that because of the high visibility and control, large companies will end up paying a higher tax burden.

Ambiguous results have led to a number of empirical studies. Several authors have estimated directly the size of the Company's effective tax rate. Siegfried (1972) estimate such a relationship the U.S. and although the results seem to be influenced by a large presence of large companies in some sectors, finds a negative relationship between size (measured by assets) and effective taxation. His results are consistent with the theory of political power and a similar relationship is also found by Pocarno (1986). Such a negative relationship is however in contrast with the findings of Watts and Zimmerman (1978), using U.S. data for 1948-1981 and believes that in 1971, the largest fifty companies were faced with significantly higher rates of tax actual profit which confirms rather political cost theory. In other studies, Gupta and Newberry (1997) for the U.S. and Janseen and Buijink (2000) for the Netherlands found no strong evidence of a relationship, both using total assets to measure firm size. Depending thus on how autonomy of planning on taxes rewards, political influence and dominance of decision making then takes route to shape progress and future company plans.

\subsection{Empirical Review}

\subsubsection{Asset Tangibility and Firm Value}

Kiesewetter and Manthey (2017) investigated the influence of tax planning of firm value creation of European companies across 20 different countries with a panel data set with eight thousand observations from the year 2005 to 2014 . The study employed Tobin's Q ratio as the operational indicator of the independent variable, firm value. The independent variables had four proxies; assets tangibility, liquidity, effective tax rate and valuation aspect. The ratio of book value of property plant and equipment to lagged asset was employed to capture assets tangibility, liquidity was measured as the ratio of cash to lagged assets whiles price to book value of equity operationalised valuation aspects. The study sourced panel data from Thomson Reuters database. Ordinary least squares regression was used to test the hypotheses and included industry, year and country specific fixed effects. Findings of the study revealed that found that asset tangibility had a positive and a statistically significant association with firm value creation. However, effective tax rate was found to have a negative and a significant association with firm value creation. Nonetheless, liquidity and valuation aspect were found to have had a not statistically significant influence.

Christina and Alexander (2019) examined whether firm value of manufacturing firms listed in the Indonesia stock exchange was affected by tax planning practices they had put in place. Firm size and effective tax rate were adopted as independent variables. Firm size was measured as the natural $\log$ of the 
firms' total assets where as effective tax rate was indicated by the ratio of income tax charge to earnings before tax. The dependent variable firm value was proxied by return on assets. The study targeted 37 listed manufacturing companies and covered the period 2014 to 2016. Panel data used in the study was obtained from the financial statements of the manufacturing companies. Empirical analysis was carried out using multiple linear regression model. The results of the study indicated that tax planning had a negative and statistically significant effect on firm value.

Mogote et al. (2019) sought to analyse how capital intensity of manufacturing companies in Kenya affect their financial performance. The study defined capital intensity as the extent to which the firm had invested in tangible non-current assets. The focus of the study was on the nine manufacturing firms listed at the Nairobi securities exchange between 2010 and 2017. Capital intensity, measured as non-current assets as a ratio of total assets was adopted as the independent variable while return on assets and return on equity were adopted as the proxies of financial performance, the dependent variable. The tax planning theory, the political power theory the tradeoff theory and agency cost theory provided theoretical anchorage to the study. The research was conducted using explanatory research design and utilised panel data for the manufacturing entities spanning 8 years. The data was obtained from financial statements of the targeted firms and linear regression model was used to estimate the relationship. The findings of the study indicated that capital intensity had positive and insignificant association with financial performance. Mogote et al. (2019) thus concluded that tax palling as proxied by capital intensity did not affect financial performance of listed manufacturing firms in Kenya.

\subsubsection{Leverage and Firm Value}

Oeta et al. (2019) examined tax planning activities and their impact on financial performance of manufacturing firms in Kenya. The study assessed the relationship between selected tax planning activities: leverage and expenditure on research and development on financial performance. Return on assets was adopted as the financial performance measure while leverage was measured as debt-to-equity ratio. Data on manufacturing firm's performance was obtained from yearly published financial statements for the period 2010 to 2017. The study was undertaken on 9 manufacturing firms that were listed at the Nairobi securities exchange. The study employed pooled data and ordinary least squares estimation technique with panel data methodology. The findings of the study indicated that leverage had a negative but insignificant association with firm performance as measured by return on assets. In regards to research and development expenditure, the study findings indicated a positive but a statistically insignificant relationship with financial performance. The study thus concluded that there was no significant association between tax planning and financial performance.
Nafti, Kateb and Masghouni (2020) investigated the effect of tax evasion on firm value on a sample of 34 non-financial firms listed in the Tunisian stock exchange over an eight-year period ranging from 2007 to 2014. The dependent variable firm value was proxied by the Tobin's Q ratio computed as the ratio of market capitalization to replacement cost of total non-current assets. Two dependent variables were adopted as measures of tax planning. These were leverage which was measured as long-term debt divided by total asset and effective tax rate operationalised as percentage of total tax charge to before tax income. The study was premised on three theories: agency theory; stakeholders' theory and the regulatory theory. Nafti et al. (2020) employed regression analysis on a panel data set of the 34 targeted firms for the eight years making a sum of 272 firm years observations. Based on the results of the Hausman tests, the study opted for the fixed effect model regression. Results of the study indicated that leverage had a positive and significant association with firm value. Effective tax rate was found to have negative but insignificant association with firm value. Bhagiawan and Mukhlasin (2020) empirically investigated the impact of tax planning on firm value using Indonesian listed manufacturing firm for the period 2016 to 2018 with 266 firm-year observations. The study employed secondary data obtained from published financial statements of each firm and multiple linear regression used to obtain the variables coefficients. Leverage, measured as by the debt equity ratio and firm size measured as company's total assets were adopted as tax planning measures (independent variables) whereas Tobin's Q was adopted as the proxy for the dependent variable, firm value. The study revealed negative but insignificant association between leverage and firm value. Tax planning as measured by firm size was also found to have a negative but insignificant association with firm value.

Omesi and Appah (2021) examined the impact of corporate tax planning on firm value of listed companies in Nigeria for the period between 2015 and 2019. Two variables, leverage and capital intensity were adopted as the proxies for tax planning. Leverage was measured as the ratio of total longterm debt to total assets. On its part, capital intensity computed as the quotient of tangible asset to total assets. The dependent variable, firm value was explained using the Tobin's Q formula, market value of the firms' total assets dividend by the replacement cost of total assets. In the study, ex-post facto and correlational research designs were adopted. Simple random sampling was adopted in selection of 26 firms that were listed at the Nigerian stock exchange as of the last day of 2019. Secondary data relating to the variables was obtained from financial statements of the sampled companies. For purposes of data analysis, the study employed pooled ordinary least squared method. Findings of the study revealed that leverage had a positive but an insignificant association with firm value while capital 
intensity had negative but also insignificant association with firm size.

\subsubsection{Effective Tax Rate and Firm Value}

Assidi, Aliani and Omri (2016) examined the association between the corporate tax optimization and the firm's value in the Tunisian context over an 11-year period. The study employed the effective tax rate, financial debt and capital expenditure as proxies for tax optimization. Effective tax rate was measured as income tax divided by income before tax, financial debt was operationalised as financial debt as a ratio of equity whereas capital expenditure was indicated by the gross change in tangible assets. On the other hand, an accounting measure, return on asset was used as the measure of firm value. The survey targeted listed and non-listed Tunisian firms. However, firm in the financial sector were excluded from the study. The study used secondary data obtained from the stock market authority in the case of listed firms while data relating to non-listed firms were obtained from the financial statements of each firm. Findings of the study revealed a negative relationship between corporate tax optimization and firm value for Tunisia firms indicating that minimization of the tax rate had a direct impact on the firm's profitability.

Izevbekhai and Odion (2018) investigated the association between tax planning and firm value using a sample of 87 firms that were quoted in the Nigeria stock exchange in the period between 2010 and 2016. The study employed secondary panel data obtained from financial statements of each of the firms resulting and obtained a balanced panel with 609 firm years observations. The explanatory variable tax planning was operationalised as effective tax rate while the firm value was indicated by the Tobin's Q ratio. Capital intensity, measured as the ratio of tangible non-current assets to total assets was adopted as a control variable, Fixed effect model was adopted in estimating the coefficients. Findings of the study revealed that effective tax rate as a measure of tax planning had negative, but insignificant association with firm value. The moderating influence of capital intensity was also found not be significant.

Kirkpatrick and Radicic, (2020) examined the influence of tax planning activities on the firm value of listed corporates in the United Kingdom. The study adopted market value of equity per share as the dependent while the independent variables was effective tax rate which was taken as tax expense dividend by pre-tax profit, long term debt per share and tax per share which was computed as annual income tax dividend by number of ordinary shares. The study sampled 70 large firms drawn from the UK FTSE 100 over a five-year period 2000 to 2010.The static panel data analysis employed by the study revealed a positive and statistically significant relationship between tax per share and firm value. On the other hand, effective tax rate was found to a positive, but statistically insignificant relationship with firm value. The study was however undertaken on the United Kingdom and the findings may not be generalised in a Kenyan situation. Further, the study was undertaken more than a decade ago and the study can be extended to cover more recent years.

$\mathrm{Vu}$ and Le (2021) adopted effective tax rate as a proxy for tax planning and examined its effect on firm value of quoted companies in Vietnam over the period 2015 to 2019. Further, the study examined the moderating influence of state control in the relationship between tax planning and firm value. The proxy for the independent variable, effective tax rate was measured as the ratio of total tax to earning before tax. On the other hand, the moderator, state control was measured as the state equity holding as a proportion of total equity shares. Firm value was adopted as the dependent variable and measured using the Tobin's Q ratio. In the study, the ratio was computed as total assets less book value of equity plus market value of equity all dividend by total assets ( Vu \& Le, 2021). Two theories, the agency theory and the political power theory were used to provide anchorage to the study. The study adopted the longitudinal research design and employed pooled ordinary least squares to test the hypothesised relationship. Purposive sampling was employed by the study in selecting 513 non-financial firms that were listed in the Vietnam securities exchange over a five-year period 2015 to 2019. Secondary panel data was obtained from the stock market regulatory authority in Vietnam. Based on the study findings, tax planning was found to have a negative effect on firm value and that this association was strengthened by state ownership.

\subsection{Conceptual Framework}

Based on reviewed empirical literature, a conceptual framework was developed to guide the present study. The study adopted assets tangibility, leverage, and effective tax rate as the independent variables. Firm value was taken as the dependent variable. They are represented in the schematic diagram in Figure 2.1 which was adopted as a guide to show the interrelation among the key variables of the study.

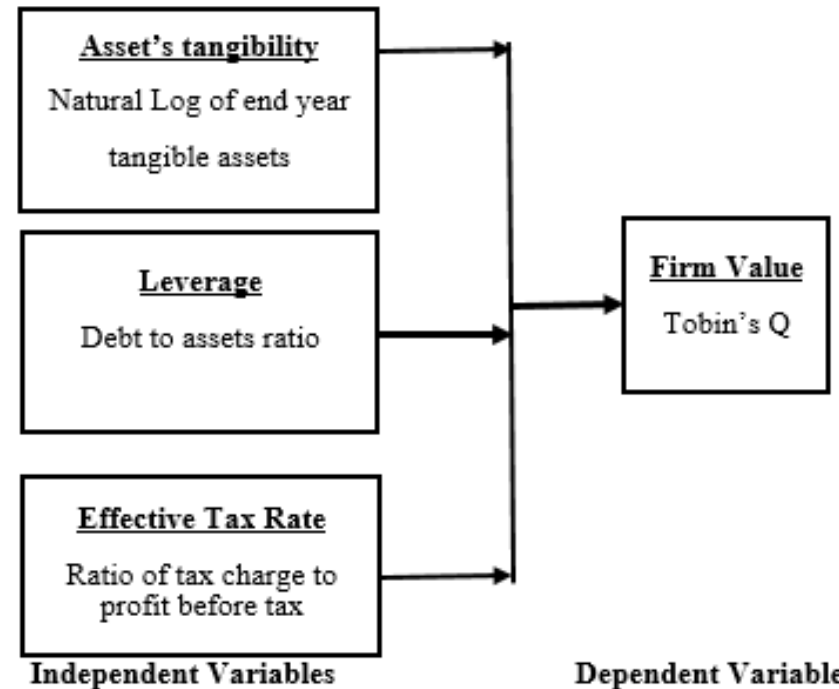

Figure 2.1 Conceptual Framework 
CHAPTER THREE

\section{RESERCH METHODOLOGY}

\subsection{Introduction}

This chapter deals with the research design, population, data collection, processing and analysis. It gives out the projected measurable attributes of the firms and variables included in the study and applicable statistical techniques in investigating the effect of tax planning variables on the firm value manufacturing firms listed at the Nairobi Securities exchange.

\subsection{Research Design}

This study adopted longitudinal research survey. Also known as panel data survey, longitudinal research design involves unit of analysis being followed at specified intervals over a long period of time, in most cases years (Cooper \& Schindler, 2014). The key feature of panel studies is that the crosssectional unit is surveyed over time thus providing very useful information on the dynamics of the variable (Gujarati \& Sangeetha, 2013).

\subsection{Target Population}

The population of this study was all the manufacturing companies listed on the manufacturing, construction and allied sectors of the Nairobi Securities Exchange. According to The Capital Markets Authority (2021), there were 13 manufacturing firms listed in the two sectors as of December 2020. Due to the small number of firms, the study shall opt for census and hence sampling will not be required. A list of the manufacturing firms is presented in Table 3.1.

Table 3.1: Manufacturing Firms listed at the Nairobi Securities Exchange

\begin{tabular}{ll}
\hline \multicolumn{2}{l}{ Manufacturing Firms } \\
\hline 1 & ARM Cement Limited \\
2. & Bamburi Cement Limited \\
3. & Crown Paints Kenya PLC \\
4. & East African Cables PLC \\
5 & East Africa Portland Cement PLC \\
6. & BOC Kenya PLC \\
7. & British American Tobacco Kenya PLC \\
8 & Carbacid Investment PLC \\
9. & East African Breweries PLC \\
10. & Mumias Sugar Company PLC \\
11. & Unga Group Limited \\
12. & Kenya Orchards Limited \\
13. & Flame Tree Group Holdings Limited \\
\hline
\end{tabular}

Source: (Capital Markets Authority, 2021)

\subsection{Data Collection}

This study used secondary panel data collected from each firms audited and published financial statements. The study considered the most recent ten years as the study period, but excluded year 2020 as firm value could have been affected by the health crises firm value. Thus, the study targeted study period was the ten years between 2010 and 2019.

Four firms were dropped for further analysis due to varied reasons. For instance, ARM cement limited and Mumias Sugar company plc were dropped for further analysis for the reason that they had been suspended for the Nairobi Securities Exchange during the study period. Frame Tree Group holdings had been registered in the course of the study period, while as most of the published financial statement of Kenya Orchards limited were unavailable. In the end, only nine companies were analysed. Table 3.2 is a list of manufactured firms that were included in final analysis.

Table 3.2: Manufacturing Firms Included in The Final Analysis

\begin{tabular}{cl}
\hline Manufacturing Firms \\
\hline 1. & Bamburi Cement Limited \\
2. & Crown Paints Kenya PLC \\
3. & East African Cables PLC \\
4. & East Africa Portland Cement PLC \\
5. & BOC Kenya PLC \\
6. & British American Tobacco Kenya PLC \\
7. & Carbacid Investment PLC \\
8. & East African Breweries PLC \\
9. & . \\
\hline
\end{tabular}

Source: (Capital Markets Authority, 2021)

\subsection{Operationalization of Study Variables}

To enable the testing of the formulated hypotheses, the study variables must be operationalised. According to Cooper and Schindler (2014), operationalization gives meaning to a concept by specifying the operations necessary to mearsure it. The variables of this study includeded tax palnning as the independent variable and firm value as the dependent variable. Operationalisation of the variables was based on examination of previous empirical studies. A summary of the operationalised variables is presented in Table 3.3. 
"Effect of Tax Planning on Firm Value of Manufacturing Firms Listed At the Nairobi Securities Exchange"

Table 3.3: Operationalization of Variables

Variable Operationalization

Supporting Literature

\begin{tabular}{|c|c|c|}
\hline Firm Value & Tobin's $Q=\frac{\text { Equity at market value+Liablilities at book value }}{\text { Assets at book value }}$ & $\begin{array}{l}\text { Izevbekhai and Odion, (2018), } \\
\text { Omesi and Appah, (2021) }\end{array}$ \\
\hline Leverage & $\frac{\text { Total debt at book value }}{\text { Total Assets at book value }}$ & $\begin{array}{l}\text { Oeta et al., (2019) } \\
\text { Omesi and Appah, (2021) }\end{array}$ \\
\hline Asset Tangibility & $\begin{array}{l}\text { Natural logarithm of book value of tangible assets at the end } \\
\text { of the year. }\end{array}$ & $\begin{array}{l}\text { Mogote et al. (2019) } \\
\text { Christina and Alexander ( 2019) }\end{array}$ \\
\hline Effective Tax Rate & $\frac{\text { Tax charge }}{\text { Profit Before Tax }}$ & $\begin{array}{l}\text { Izevbekhai and Odion (2018) } \\
\text { Kirkpatrick and Radicic (2020) } \\
\text { Vu and Le (2021) }\end{array}$ \\
\hline
\end{tabular}

\subsection{Data Processing, Analysis and Presentation}

Data processing involves the cleaning of raw data to ensure that it is consistent with the requirement for estimating the variables. Secondary data was extracted from the audited and published financial reports and was used to come up with relevant measures as defined in Table 3.3 Operationalization of the study variables. This study adopted panel data regression analysis model. The Analysis was aided by the STATA statistical software. Panel data regression analysis consists of three models: pooled ordinary least squares (OLS), the Random Effect Model (REM)and the Fixed Effect Model (FEM)
In deciding the appropriated model between the pooled OLS, FEM and REM appropriate diagnostic and specification tests, summarised in Table 3.4 were carried out. The diagnostic tests were carried out to ensure non violation of classical linear regression assumptions. Non violation of any of the assumptions allows for the adoption of the, pooled OLS. On the other hand, if the assumptions are violated, in the Hausman specification tests are used in determining between the random effect model and the fixed effect model. Thereafter, descriptive statistics, correlational and inferential analysis were used to summarise status of leverage, assets tangibility, effective tax rate and firm value among listed manufacturing firms in Kenya.

Table 3.4: Key Diagnostic Tests

\begin{tabular}{lll}
\hline Key Diagnostic Test & Sample Statistics & Interpretation \\
\hline Normality Tests & Shapiro Wilk test & $\begin{array}{l}\text { Values less than 0.05 indicates that data is } \\
\text { normally distributed. } \\
\text { Multicollinearity Test }\end{array}$ \\
Variance Inflation Factor (VIF) test & $\begin{array}{l}\text { VIF values between 1- 10, indicates no } \\
\text { multicollinearity. } \\
\text { VIF values less than 1 or greater than 10, } \\
\text { indicates multicollinearity }\end{array}$ \\
Autocorrelation Test & Woolridge test & $\begin{array}{l}\text { A p-value less than one means no } \\
\text { autocorrelation exists. } \\
\text { p- value }<0.05, \text { this indicates that the data }\end{array}$ \\
Model Specification & Likelihood Ratio & $\begin{array}{l}\text { is not heteroskedastic } \\
\text { p-value less than } 0.5 \text { use random effect p- } \\
\text { value greater than } 0.5 \text { use fixed effects }\end{array}$ \\
\hline
\end{tabular}

\subsection{The Analytical Model}

Based on other models that have been used to test the effect of tax planning on firm value and operationalization of study variables as presented in Table 3.3, the present study adopted the analytical model presented as model 1.
FirVal $_{\text {it }}=\beta_{0}+\beta_{1}$ Lev $_{\text {it }}+\beta_{2}$ AssetTang $_{\text {it }}+\beta_{3}$ ETR $_{\text {it }}+\varepsilon--------$ Model (i)

Where: -

FirVal ${ }_{i t}=$ Firm Value per firm over time $\beta_{0}=$ Constant 
$\beta_{1}, \beta_{2}, \beta_{3}$, are regression coefficients of the three independent variables

$\operatorname{Lev}_{\text {it }}=$ leverage per firm over time

AssetTang $_{i t}=$ Asset tangibility per firm over time

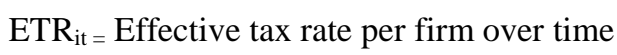
$\dot{\varepsilon}=$ Error term

Results of the regression model were interpreted as provided in Table 3.5.

Table 3.5: Interpretation of Results

\begin{tabular}{|c|c|c|}
\hline Statistical Question & Statistic & Interpretation \\
\hline Strength of relationship between $\mathrm{X}$ and $\mathrm{Y}$ & $\mathrm{R}$ & $\begin{array}{l}\text { A higher } \mathrm{R} \text { indicates a stronger } \\
\text { relationship. Conversely, a low } \mathrm{R} \text { value } \\
\text { indicates a week association }\end{array}$ \\
\hline Explanatory power of the model & R-square & $\begin{array}{l}\text { Higher R-square value indicates that } \\
\text { independent variables explain the } \\
\text { variation in } \mathrm{Y} \text { by a higher percentage. }\end{array}$ \\
\hline Is the model statistically significant & p-value & $\begin{array}{l}\text { If the p-value statistic is lower than the } \\
\text { stated significant level, the model is } \\
\text { statistically significant }\end{array}$ \\
\hline $\begin{array}{l}\text { The effect of dependent variable on independent } \\
\text { variable }\end{array}$ & $\begin{array}{l}\text { Sign of the } \\
\text { coefficient }\end{array}$ & $\begin{array}{l}\text { A positive value indicates that the } \\
\text { independent variable positively } \\
\text { A negative value indicates that the } \\
\text { independent variable has an inverse } \\
\text { effect on the dependent variable }\end{array}$ \\
\hline Significance of the individual variable & p-value & $\begin{array}{l}\text { The lower the } p \text {-value, the more } \\
\text { significant the variable is }\end{array}$ \\
\hline
\end{tabular}

\section{CHAPTER FOUR}

\section{DATA ANALYSIS, RESULTS AND DISCUSSIONS}

\subsection{Introduction}

This chapter presents the results of analysis of secondary data collected in line with the research design outlined in chapter three. Analysis of data involved descriptive statistics meant for statistical analysis, carrying out diagnostic tests on the data to determine suitability for statistical analysis, estimating the regression models and discussion of the results in relation to empirical literature. The computed data for firm value, which was proxied by Tobin's Q, leverage, effective tax rate and asset tangibility was analysed using panel data regression model with the help of Stata software version 12. Diagnostic tests were applied on the data as pre-test condition.

\subsection{Description Statistics}

This section presents the summary of panel statistics for the entire sample. The summary statistics considered included the mean, standard deviation, minimum and maximum values. Descriptive data analysis was undertaken to determine the statistical properties of the data used in the study. In addition, descriptive statistics allow the researcher to digest and understand large volumes of data and enhance effective communication to users (Cooper \& Schindler, 2014). The study used data for 9 manufacturing firms listed at the Nairobi Securities Exchange for a ten-year period 2010 to 2019. Table 4.1 indicates the summary of descriptive statistics of the firms.

Table 4.1: Panel Variables Summary Statistics

\begin{tabular}{lllll}
\hline $\begin{array}{l}\text { Variable/ } \\
\text { Statistics }\end{array}$ & $\begin{array}{l}\text { Firm Value } \\
\text { (Tobin's Q) }\end{array}$ & $\begin{array}{l}\text { Leverage } \\
\text { (Ratio) }\end{array}$ & $\begin{array}{l}\text { Effective tax rate } \\
\text { (Ratio) }\end{array}$ & $\begin{array}{l}\text { Assets Tangibility } \\
\text { (Natural Log) }\end{array}$ \\
\hline Obs & 85 & 85 & 85 & 85 \\
Mean & 897.9176 & .4815424 & .2597553 & 11.34176 \\
Std. Dev & $1,152.936$ & .2299653 & .3013481 & 2.428872 \\
Min & 12 & .0116 & -1.0168 & 7.31055 \\
Max & 5,657 & 1.2928 & .8699 & 15.22049 \\
\hline
\end{tabular}

Results in table 2 indicates that the total mean of firm value for the period 2010 to 2019 was 897.92 indicating that all the sampled the manufacturing firms listed in the Nairobi Securities Exchange during the study period were financially sound. However, the corresponding standard deviation of
1,152.936 showed a large variability in firm value over time. This implied that some companies created huge value while others reduced value. The minimum and maximum values of firm over the same period were 12 and 5,657 respectively. The results on leverage as indicated by leverage ratio shows 
a mean of .4815424 or 48 percent which indicates that firms were leveraged to the tune of 48 percent. The standard deviation of the variable was 23 percent for the period 2010 to 2019. At the same time the maximum leverage was indicating 1.3 (100.3 percent) and a minimum value of 0.012 . The results indicate a wide variation in debt financing over the study period. Meanwhile, the average for effective tax rate was 0.2597 which indicates that the effective tax rate for the firms over the ten year study period was 25.97 per cent. The maximum of the ETR stood at -1.0168 while the maximum was 0.8699 while the standard deviation is recorded at 0.30135 . This indicated that while some firm were able to save on tax, others firms effective tax rate was as high as 86.99 per cent. The results also show that the mean of the natural $\log$ of assets tangibility for the then year period was 11.84 with a standard deviation of 2.43 indicating a small variability in assets tangibility over time. The maximum and minimum values for asset tangibility over the same time was 7.31 and 15.22 respectively.

\subsection{Model Diagnostic Tests}

To accurately use regression analysis, the basic assumptions of the multiple linear regression must be observed (Gujarati \& Sangeetha, 2013). The suitability of panel data for statistical analysis was determined by carrying out various tests aimed at investigating if the essential requirements of classical linear regression were fulfilled. The tests included the normality tests, multicollinearity test, panel unit root test, autocorrelation test and the heteroscedasticity test Where the assumptions were violated, appropriate remedial actions were applied. Panel cointengration tests were carried out to establish if the study variables had a long run association. The Hausman specification test was carried out to establish which estimation effects, fixed or random provided superior results for the study. The results and statistical interpretation of the various test carried out is presented in this section.

\subsubsection{Normality Tests}

To test for normality of the data, the study adopted the Shapiro Wilk test. The usefulness of normal distribution stems from the that when assumption is violated, interpretation and inference may not be valid or reliable. Shapiro-Wilk test is favoured as it is more conclusive than graphical method. The null hypothesis under this test is that disturbances are not normally distributed if $\mathrm{P}$-value is more than 0.05 at 5 percent level. The alternative hypothesis is that disturbance terms are normally distributed if $p$-value is less than 0.05 . Table 4.2 presents the normality tests results.

Table 4.2: Shapiro-Wilk $W$ test for normal data

\begin{tabular}{llllll}
\hline Variable & Obs & W & V & $\mathbf{Z}$ & Prob>z \\
\hline Firm Value & 85 & 0.72392 & 19.919 & 6.577 & 0.00000 \\
Leverage & 85 & 0.94740 & 3.795 & 2.932 & 0.00168 \\
Effective Tax Rate & 85 & 0.72501 & 19.840 & 6.569 & 0.00000 \\
Log Asset Tangibility & 85 & 0.90565 & 6.807 & 4.217 & 0.00001 \\
\hline
\end{tabular}

Results in Table 4.2 show all the p-value were less than 0.05 and thus the null hypothesis was rejected and the alternative accepted that data was normally distributed.

\subsubsection{Multicollinearity Test}

Multicollinearity occurs when two or more predictor variables in a regression equation are highly correlated making it impossible to estimate equations with precision and accuracy due to either variables becoming indeterminate or possession of large standard errors (Gujarati \& Sangeetha, 2013). To identify if multicollinearity existed, the study adopted the Variance Inflation Factor (VIF). VIF values greater than 10 indicated the presence of multicollinearity. Results of the test are indicated in Table 4.3.

Table 4.3: Variance Inflation Factor

\begin{tabular}{lll}
\hline Variable & VIF & 1/VIF \\
\hline Effective Tax Rate & 1.00 & 0.998637 \\
Leverage & 1.00 & 0.998691 \\
Log Asset Tangibility & 1.00 & 0.998690 \\
\hline
\end{tabular}

The results in Table 4.3 presents variance inflation factor results which are all less than 10 . The study concluded that there was no Multicollinearity and thus the model was deemed fit for further analysis.

\subsubsection{Test for Autocorrelation}

To establish whether or not the residuals were serially correlated over time, Breusch Pagan Langrage Multiplier
(LM), Pesaran Scaled Langrage Multiplier and Pesaran Cross sectional Dependence (CD) tests were carried out. The null hypothesis was that no first order serial alternatively referred to as autocorrelation existed if $\mathrm{p}$-value was less than 0.05 . The study findings are presented in Table 4.4. 
Table 4.4: Serial Correlation Tests

\begin{tabular}{lll}
\hline Test & Statistic & P-Value \\
\hline Breusch Pagan Langrage Multiplier & 61.44983 & 0.0052 \\
Pesaran Scaled Langrage Multiplier & 2.999291 & 0.0027 \\
Pesaran Cross sectional Dependence & 3.752371 & 0.0002 \\
\hline
\end{tabular}

The output in table 4.4 was computed for the three tests. The results show that the p-value for all the three tests was less than 0.05 . This implies that at 5 percent level of significance, the p-value was not significant and hence the study failed to reject the null hypothesis of no autocorrelation and concluded that the residuals were not auto correlated.

\subsubsection{Heteroscedasticity Test}

The study adopted Breusch-Pagan /Cook-Weisberg test for heteroscedasticity. The null hypothesis was that there was no heteroscedasticity and as such the error terms had constant variance and the results are displayed in Table 4.5.

Table 4.5: Breusch-Pagan / Cook-Weisberg test for Heteroskedasticity

\begin{tabular}{ll}
\hline Chi-square (1) & 25.61 \\
Prob $>$ chi-square & 0.0000 \\
\hline
\end{tabular}

As the p-values were less than 0.05 , this indicated that the data was homoscedastic.

\subsubsection{Hausman Specification Test}

When performing panel data analysis, there is need to determine whether to run a Fixed Effects Model (FEM) or Random Effects Model (REM). Hausman specification test was used to determine whether fixed or random effects should be used in the model. The statement of null hypothesis for the was the random effect regression is appropriate at 5 percent significant level. The findings of the study are presented in Table 4.6

Table 4.6: Test for Fixed Effects or Random Effects

\begin{tabular}{lll}
\hline Test Summary & Chi-Square Statistic & p-value \\
\hline Hausman & 0.662 & 0.8815 \\
\hline
\end{tabular}

Findings in Table 4.6 indicate a p-value of 0.08815 indicating the model was statistically significant at 5 percent level of confidence, Therefore, the null hypothesis for the model was rejected hence Fixed Effects Model was used in estimating the coefficients of the model.
To allow for examination on the nature of association among the variables, correlation analysis was conducted. The correlation matrix in Table 4.8 presents the results.

Table 4.7: Correlation Matrix Results

\begin{tabular}{lllll}
\hline Variable & Firm Value & Leverage & ETR & Asset Tangibility \\
\hline Firm Value & 1.0000 & & & \\
Leverage & -0.1018 & 1.0000 & & \\
ETR & 0.3538 & & & \\
& 0.3658 & 0.1793 & 1.0000 & \\
Asset Tangibility & 0.0006 & 0.1006 & & 1.0000 \\
& 0.3087 & 0.0804 & 0.1754 & \\
\hline
\end{tabular}

The results of the study show that leverage had a negative but statistically insignificant association with firm value. However, effective tax rate association with firm value was found to be positive and statistically significant. Similarly, assets tangibility was also found to have a positive and statistically significant association with firm value. The results revealed that effective tax rate and assets tangibility were found to increase firm value while leverage diminished firm value.

\subsection{Regression Analysis}

The general objective of the present study was to examine the effect of tax planning on firm value of manufacturing firms listed in the Nairobi Security Exchange. To achieve the objective, and since the assumptions of the classical linear 
regression were not violated, and the Hausman specification test pointed toward fixed effect model, the study adopted FEM linear regression model. To run the data, the Stata statistical software was used to analyse the pooled panel data for 85 firm observations, which represented 9 manufacturing firms over a 10-year period. The results are presented in Table 4.8 where firm value measured by Tobin's $Q$ ratio was regressed on leverage, effective tax rate and assets tangibility. Table 4.9 showed the results of regression analysis of tax planning and firm value.

Table 4.8: Panel Least Squares Analysis

\begin{tabular}{|c|c|c|c|c|c|c|}
\hline Source & SS & $d f$ & MS & Number of obs & $=$ & 85 \\
\hline Model & 25365806.3 & 3 & 8455268.75 & $\begin{array}{l}\mathrm{F}(3, \\
\text { Prob > F }\end{array}$ & $=$ & $\begin{array}{r}7.94 \\
0.0001\end{array}$ \\
\hline Residual & 86292086.2 & 81 & 1065334.4 & $\mathrm{R}$-squared & $=$ & 0.2272 \\
\hline Total & 111657892 & 84 & 1329260.62 & $\begin{array}{l}\text { Adj R-squared } \\
\text { Root MSE }\end{array}$ & $\begin{array}{l}= \\
=\end{array}$ & $\begin{array}{l}0.1986 \\
1032.2\end{array}$ \\
\hline
\end{tabular}

\begin{tabular}{|c|c|c|c|c|c|c|}
\hline tobinsq & Coef. & std. Err. & t & $\mathrm{P}>|\mathrm{t}|$ & [95\% Conf. & Interval] \\
\hline finstruc & 2151.026 & 490.0332 & 4.39 & 0.000 & 1176.014 & 3126.038 \\
\hline etr & 850.5929 & 373.965 & 2.27 & 0.026 & 106.5198 & 1594.666 \\
\hline lnasset_tangibility & -8.713176 & 46.36844 & -0.19 & 0.851 & -100.9718 & 83.54548 \\
\hline _cons & -260.0157 & 598.4549 & -0.43 & 0.665 & -1450.753 & 930.7219 \\
\hline
\end{tabular}

From Table 4.8 the estimation equation $\mathrm{i}$

FirVal $_{i t}=\beta_{0}+\beta_{1}$ Lev $_{i t}+\beta_{2}$ AssetTang $_{i t}+\beta_{3}$ ETR $_{\text {it }}+\varepsilon$

was fitted as indicated in equation ii:

$$
\begin{gathered}
\mathrm{Y}=-260.02+2,151.03 \mathrm{Lev}_{\mathrm{i}}+850.59 * \text { AssetTang }_{\mathrm{it}}- \\
8.71 * \mathrm{ETR}
\end{gathered}
$$

Where: -

FirVal $_{i t}=$ Firm Value per firm over time

Lev $_{\text {it }}=$ Leverage per firm over time

AssetTang $_{i t}=$ Asset tangibility per firm over time

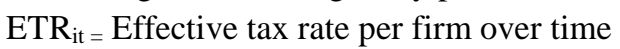

This indicated that holding all independent variables constant, the value of Tobin's, a measure of firm value was -260.02 . Hence, in the study period, manufacturing firms would have a negative value if they did not carry out any tax planning activities. The model showed that holding all other independent variable constant, a one unit increase in debt financing resulted to a 2,151.03 increase in firm value, a one unit increase in tangible assets would yield an 850.59 increase in firm value and, effective tax rate was inversely related to the tune of -8.71 with firm value.

The findings showed that tax planning variables jointly explained a 22.72 percent variation in firm value of the listed manufacturing firms. This was evidenced by the coefficient of determination $\left(\mathrm{R}^{2}\right)$ whose value was 0.2272 . This reflected a fairly good measure of fit for the variables included in the model. Moreover, the F-statistics whose p-value was 0.0001 indicated that the coefficients of all the three variables were jointly statistically different from zero at 95 percent level of confidence.

\subsection{Hypotheses Testing}

The general objective of this study was to examine the effect of tax planning on firm value of manufacturing firms listed at the Nairobi Securities Exchange. To achieve this, specific objectives were set and corresponding hypotheses stated. Panel Least Square method was used to test the individual and combined effects at 95 percent significant level $(p<0.05)$. The coefficients of determination and t-values were also extracted.

Decision points to reject or fail to reject a hypothesis were based on p-values. The study failed to reject the hypotheses if $p<0.05$ and rejected a hypothesis if $p>0.05$. The coefficient of determination $\left(\mathrm{R}^{2}\right)$, the F-statistic and beta $(\beta)$ values were the basis for results interpretation and subsequent discussions. The coefficient of determination indicated the variation in dependent variable that was explained by the independent variable where a high $\mathrm{R}^{2}$ was interpreted to mean higher explanatory power of the model. In addition, a higher Fstatistic meant the more significant the model was. The sign of the beta, either positive or negative, explained the direction of the effect of the independent variable on the dependent variable. The findings are presented in the subsections that follows.

\subsubsection{Assets Tangibility and Firm Value}

The first specific objective in this study was to evaluate the influence of assets' tangibility on firm value of manufacturing firms listed at the Nairobi Securities Exchange. A corresponding hypothesis was formulated in its null form as $\mathrm{H}_{01}$ : Assets' tangibility has no significant influence on firm value of manufacturing firms listed at the Nairobi Securities Exchange in Kenya. Assets' tangibility was operationalised as the natural log of book value tangible assets held by the firms at the end of the year while firm value was indicated by Tobin's Q ratio. Table 4.9 shows the results for influence of assets tangibility on firm value 
Table 4.9: Influence of Assets' Tangibility on Firm Value

. reg tobinsq lnasset_tangibility

\begin{tabular}{|c|c|c|c|c|c|}
\hline Source & SS & $d f$ & MS & Number of obs & 85 \\
\hline Model & 56730.3645 & 1 & 56730.3645 & $\begin{array}{l}\text { F( 1, } \\
\text { Prob }>F\end{array}$ & $\begin{array}{r}0.04 \\
0.8378\end{array}$ \\
\hline Residual & 111601162 & 83 & 1344592.31 & $\mathrm{R}$-squared & 0.0005 \\
\hline Total & 111657892 & 84 & 1329260.62 & Root MSE & $\begin{array}{l}=1159.6 \\
=110\end{array}$ \\
\hline
\end{tabular}

\begin{tabular}{|c|c|c|c|c|c|c|}
\hline tobinsq & Coef. & std. Err. & $t$ & $P>|t|$ & [95\% Conf. & Interval] \\
\hline lnasset_tangibility & -10.6995 & 52.0896 & -0.21 & 0.838 & -114.3036 & 92.90463 \\
\hline _cons & 1019.269 & 604.0272 & 1.69 & 0.095 & -182.117 & 2220.655 \\
\hline
\end{tabular}

Table 4.9 shows the results of Panel Least Squares evaluation of the influence of assets' tangibility on firm value. The coefficient of determination was 0.0005 indicating that less than 1 percent of variation in firm value was explained by assets tangibility. The remaining 99 per percent was explained by other factors not considered in the study. The overall model had a p-value of 0.838 which meant that assets' tangibility did not have a statistically significant influence on firm value. On the basis of these results, the study failed to reject the hypothesis that assets' tangibility has no significant influence on firm value of manufacturing firms listed at the Nairobi Securities Exchange in Kenya.

The findings are consistent with Mogote et al. (2019) study that found tangible assets did not have a statistically significant association with firm value. However the contradict the findings in Christina and Alexander (2019) whose results were tangible assets had a negative and statistically significant association with firm value.

\subsubsection{Leverage and Firm Value}

The second objective of the study was to determine the influence of leverage on firm value of manufacturing firms listed at the Nairobi Securities Exchange. In line with the second objective, a corresponding hypothesis was formulated as $\mathbf{H}_{02}$ : Leverage have no significant association with firm value of manufacturing firms listed at the Nairobi Securities Exchange in Kenya. Leverage was operationalised as the ratio of total debt to total assets. Table 4.10 shows the results.

Table 4.10: Influence of Leverage on Firm Value

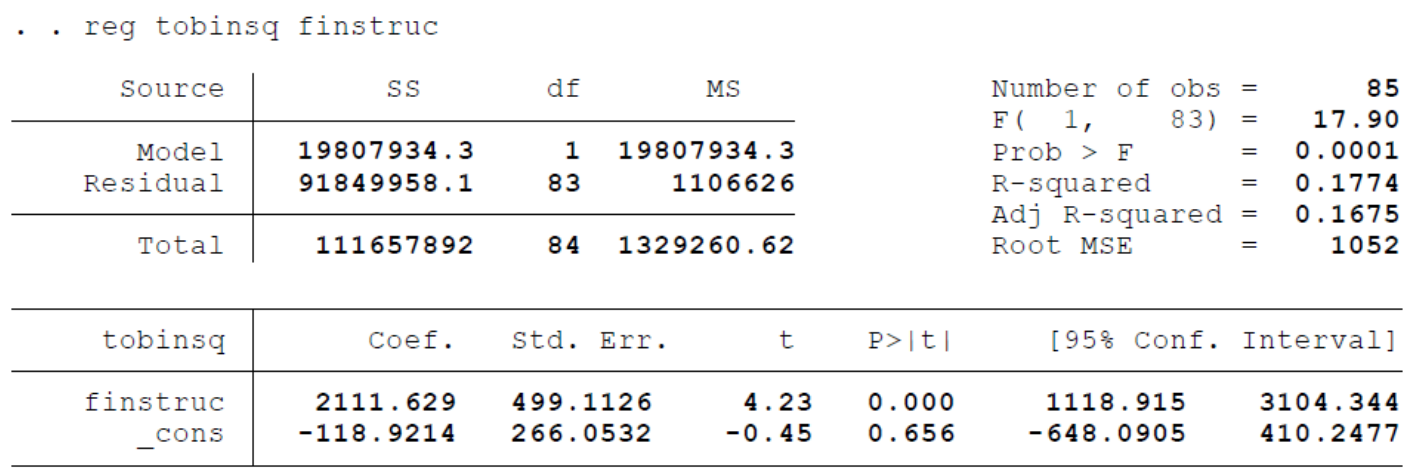

The results in Table 4.10 indicate that the independent effect of leverage on firm value were positive and statistically significant $(p<0.05)$. Overall, leverage explained 17.74 percent variation in firm value as evidenced coefficient of determination value of 0.1774 . The other 82.26 percent was explained by other variables not considered by the model.

Based on the findings, the study rejected the hypothesis, and the alternative hypothesis. leverage had a statistically significant influence on firm value was accepted. These findings are depicted in the equation as:

$$
\text { FirVal }=-118.9214+2,111.229 \text { lev }
$$

The results agreed with Nafti et al. (2020) findings that leverage had a positive and statistically significant influence with firm value. However, the results were in variance with (Bhagiawan \& Mukhlasin, 2020; Oeta et al., 2019; Omesi \&
Appah, 2021) whose findings were leverage did not have a statistically significant influence on firm value.

\subsubsection{Influence of Effective Tax Rate on Firm Value}

Establish the effect of effective tax rate on firm value of manufacturing firms listed at the Nairobi Securities Exchange. The study's third objective was to establish the effect of effective tax rate on firm value of manufacturing firms listed at the Nairobi Securities Exchange Based on the on the third objective, hypothesis 3 was formulated in it null forms as: Effective tax rate does not significantly influence on firm value of manufacturing firms listed in the Nairobi Securities Exchange in Kenya. Effective tax rate was measured as the ratio of tax charged to pre-tax profit. The results are presented in Table 4.11. 
Table 4.11: Effective Tax Rate and Firm Value

$$
\text { . . reg tobinsq etr }
$$

\begin{tabular}{|c|c|c|c|c|c|c|c|c|}
\hline source & SS & $d f$ & \multicolumn{2}{|c|}{ MS } & & $\begin{array}{l}\text { Number of obs } \\
\mathrm{F}(1,\end{array}$ & $=$ & $\begin{array}{r}85 \\
3.72\end{array}$ \\
\hline Model & 4790982.41 & 1 & \multicolumn{2}{|c|}{4790982.41} & & \multirow{2}{*}{ Prob > F } & $=$ & 0.0571 \\
\hline Residual & 106866910 & 83 & 128 & 3.13 & & & $=$ & 0.0429 \\
\hline Total & 111657892 & 84 & 132 & 0.62 & & $\begin{array}{l}\text { Adj R-squared } \\
\text { Root MSE }\end{array}$ & $=$ & 1134.7 \\
\hline tobinsq & coef. & std. & Err. & t & $P>|t|$ & [95\% Conf. & In & terval] \\
\hline etr & 792.509 & 410. & 3417 & 1.93 & 0.057 & -24.63857 & & 609.657 \\
\hline _cons & 692.0592 & 162. & 9002 & 4.25 & 0.000 & 368.0573 & & 016.061 \\
\hline
\end{tabular}

Based on the results presented in Table 4.11, effective tax rate explained four percent of the variations in firm value. The results show that effective tax rate had a positive and a statistically significant effect on firm value ( $p$-value $=0.05$ ). On the basis of these results, the study rejected $\mathrm{H}_{03}$ and accepted the alternative hypothesis. This relationship can be depicted in a model as:

$$
\text { FirVal }=692.0592+792.509 \mathrm{ETR}
$$

The findings are in sync with Kirkpatrick and Radicic (2020) whose findings revealed that effective tax rate positively influenced firm value. However, the results contradicted $\mathrm{Vu}$ and Le (2021) whose study revealed a negative relationship with firm value. Further the results varied with the finding in Izevbekhai and Odion (2018) that held effective tax rate had no effect with firm value.

\subsection{Summary of the Hypotheses}

In this section, a summary of the study findings is presented. There were three objectives out of which three hypotheses were developed and tested. The findings are presented based on the objectives and summarised in Table 4.12

\begin{tabular}{|c|c|c|}
\hline Objective & Hypotheses & Decision \\
\hline $\begin{array}{l}\text { Evaluate the influence of assets' } \\
\text { tangibility on firm value of } \\
\text { manufacturing firms listed at the } \\
\text { Nairobi Securities Exchange. }\end{array}$ & $\begin{array}{l}\mathrm{H}_{01} \text { : Assets' tangibility has no } \\
\text { significant influence on firm } \\
\text { value of manufacturing firms } \\
\text { listed at the Nairobi Securities } \\
\text { Exchange in Kenya }\end{array}$ & Failed to reject \\
\hline $\begin{array}{l}\text { Determine the influence of } \\
\text { leverage on firm value of } \\
\text { manufacturing firms listed at the } \\
\text { Nairobi Securities Exchange. }\end{array}$ & $\begin{array}{l}\mathrm{H}_{02} \text { : Leverage have no significant } \\
\text { association with firm value of } \\
\text { manufacturing firms listed at } \\
\text { the Nairobi Securities } \\
\text { Exchange in Kenya. }\end{array}$ & Rejected \\
\hline $\begin{array}{l}\text { Establish the effect of effective } \\
\text { tax rate on firm value of } \\
\text { manufacturing firms listed at the } \\
\text { Nairobi Securities Exchange. }\end{array}$ & $\begin{array}{l}\mathrm{H}_{03} \text { : Effective tax rate does not } \\
\text { significantly influence on firm } \\
\text { value of manufacturing firms } \\
\text { listed in the Nairobi Securities } \\
\text { Exchange in Kenya. }\end{array}$ & Rejected \\
\hline
\end{tabular}

Table 4.12 Summary of the Hypotheses

\section{CHAPTER FIVE}

\section{SUMMARY, CONCLUSSION AND RECOMMENDATIONS}

\section{$5.1 \quad$ Introduction}

This chapter presents a summary of findings and the conclusions of the study. Further, the chapter presents the recommendations made by the study and suggests areas for further study. Finally, the chapter presents the limitations.

\subsection{Summary of the Study}

This study sought to examine the effect of tax planning on firm value on manufacturing firms listed at the Nairobi securities exchange. The study adopted a longitudinal research design and targeted 13 manufacturing firms that were listed in both the construction and manufacturing sectors of the Nairobi securities exchange, However, due to suspension of some firm and incomplete data on others, only 9 firms were included in the final study. The study employed unbalanced panel data for the period 2010 to 2019 resulting to 85 firm-year observations

\subsubsection{Assets' Tangibility and Firm value}

The study's first objective was to evaluate the influence of assets 'tangibility on firm value of manufacturing firms that were listed in the Nairobi securities exchange. using panel least squares regression method, the study established that asset tangibility had a positive, though statistically insignificant effect on firm value. 


\subsubsection{Leverage and Firm Value}

The study second objective was to determine the influence of leverage on firm value of manufacturing firms listed at the Nairobi Securities Exchange. The study employed the ratio of total debt to total assets to operationalize leverage. Results from the regression model established that leverage had a positive and a statistically significant relationship with firm value.

\subsubsection{Effective Tax Rate and Firm Value}

The third objective of the study was to establish the effect of effective tax rate on firm value of manufacturing firms listed at the Nairobi Securities Exchange. Effective tax rate was measured as tax charged divided by profit before tax. Results of the study indicated that effective tax rate had a positive and statistically significant influence on firm value.

\subsection{Study's Conclusion}

Based on the findings of the study, the conclusions were that firm value was dependent on tax planning activity undertaken. This implies that the pecking order theory and the agency cost theory were applicable to listed manufacturing firms in Kenya. The pecking order theory insights on tax shields proved practical and useful to the study. The findings lead the study to conclude that the various tax planning activities affected firm value differently. Assets, tangibility was fund to have an insignificant association with firm value and thus the study concluded that tax planning, as proxied by assets tangibility did not have any effect on firm value. Leverage recorded the highest influence to firm value both on combined analysis and on a stand-alone basis. Effective tax rate, according to the study findings was found to have the least effect on firm value either on stand-alone basis or on a combined basis. Accordingly, the study concluded that tax planning as operationalized by leverage and effective tax rate positively impacted on firm value.

\subsection{Study's Recommendations}

This study main goal was to investigate the effect of tax planning on firm value on listed manufacturing firms in Nairobi, Kenya. Though the findings were mixed, they nonetheless will enhance the understanding of tax planning method as they are crucial and impact on firm value. The study made recommendations for further studies, methodology, policy and practice. This study recommends a more detailed analysis of other independent variables related to tax planning and with a potential to influence firm value. The examined variables explained approximately a quarter of the total variation in firm value. This implies that 77 percent of variation in firm value was as a result of other variables not considered by the model. This study focus was on listed manufacturing firms. To broaden the knowledge, the study recommends to other researcher to focus on non-listed manufacturing firms as well as all the listed firms.

\subsection{Limitations of the Study}

The study aimed at establishing the effect of tax planning on firm value of listed manufacturing companies in Kenya. Though the objectives were achieved, there were some limitations. Among the limitations, the study relied on secondary data that was obtained from published financial statements. Though the data was verifiable, it was still prone to some limitations. First, the way some firms presented the information met that some of the variables could not be obtained and hence some firms were dropped on this basis. Other firms had missing financial statements in some years resulting to unbalanced panel data. Further, the study only focused on listed manufacturing firms in Kenya. Though this made it possible to look at sector level effect of tax planning activities on firm value, it is not clear if the findings can be ported to other firms that were not targeted by the study.

\section{REFERENCES}

1. Assidi, S., Aliani, K., \& Omri, M. A. (2016). Tax optimization and the firm's value: Evidence from the Tunisian context. Borsa Istanbul Review, 16(3), 177-184. https://doi.org/10.1016/j.bir.2016.04.002

2. Bhagiawan, G., \& Mukhlasin, M. (2020). Effect of corporate governance on tax planning and firm value. International International of Commerce of Commerce and and Finance, 6(2), 72-80.

3. Capital Markets Authority. (2021). The CMA Quarterly Capital Markets Statistical Bulletin Q1.2021. Nairobi, Kenya.

4. Christina, S. (2019). The Effect of Corporate Tax Planning on Firm Value. Accounting and Finance Review, 4(20), 1-4.

5. Christina, S., \& Alexander, N. (2019). Corporate Governance, Tax Planning and Firm Value. Entrepreneurship and Business Management, 233237. https://doi.org/10.5220/0008491102330237

6. Cooper, D. R., \& Schindler, P. S. (2014). Business research methods (Twelfth Ed). New York: McGraw-Hill/Irwin.

7. Feng, H., Habib, A., \& Tian, G. liang. (2019). Aggressive tax planning and stock price synchronicity: evidence from China. International Journal of Managerial Finance, 15(5), 829-857. https://doi.org/10.1108/IJMF-07-2018-0194

8. Galpin, N. (2020). Cash holdings, costly financing and the $\mathrm{q}$ theory of returns. Accounting \& Finance Journal, 60(4), 1149-1174. https://doi.org/10.2139/ssrn.2817972

9. Government of Kenya. Tax Laws (Amendment) Act. , Pub. L. No. 2 of 2020 (2020).

10. Gujarati, D., \& Sangeetha, S. (2013). Basic Econometrics (4th Editio). Boston: McGraw-Hill.

11. Izevbekhai, O., \& Odion, A. (2018). Tax Planning and Firm Value. Nigerian Academy of Management 
Journal, 13(1), 94-116.

12. Kenya Association of Manufacturers. (2021). Manufacturing Priority Agenda. Retrieved from https://kam.co.ke/wp-content/uploads/2021/02/ 2021-Manufacturing-Priority-Agenda.pdf

13. Kiesewetter, D., \& Manthey, J. (2017). Tax avoidance, value creation and CSR - a European perspective. Corporate Governance (Bingley), 17(5), 803-821. https://doi.org/10.1108/CG-082016-0166

14. Kirkpatrick, A. K., \& Radicic, D. (2020). Tax Planning Activities and Firm Value: A Dynamic Panel Analysis. Advances in Taxation, 27(2010), 103-123. https://doi.org/10.1108/s1058749720200000027004

15. KNBS. (2020). Economic Survey. In Economic Survey. https://doi.org/10.4324/9781315016702

16. Mgammal, M. H. (2020). Corporate tax planning and corporate tax disclosure. Meditari Accountancy Research, 28(2), 327-364. https://doi.org/10.1108/MEDAR-11-2018-0390

17. Mogote, O., Kiai, R., \& Muchiri, J. (2019). Capital Intensity and Financial Performance Of Manufacturing Companies Listed At Nairobi Securities Exchange. International Journal of Scientific \& Engineering, 10(9), 1647-1658.

18. Nafti, O., Kateb, I., \& Masghouni, O. (2020). Tax evasion, firm's value and governance: evidence from Tunisian Stock Exchange. Journal of Financial Crime, 27(3), 781-799. https://doi.org/10.1108/JFC-02-2020-0023

19. Ni, Y., Cheng, Y. R., \& Huang, P. (2020). Do intellectual capitals matter to firm value enhancement? Evidences from Taiwan. Journal of Intellectual Capital, 22(4), 725-743. https://doi.org/10.1108/JIC-10-2019-0235

20. Oeta, S., Kiai, R., \& Muchiri, J. (2019). Influence of tax planning on financial performance of manufacturing companies listed at Nairobi Securities Exchange. International Journal of Research in Business and Social Science (21474478), 8(6), 262-270. https://doi.org/10.20525/ijrbs.v8i6.527

21. Omesi, I., \& Appah, E. (2021). Corporate Tax Planning and Firm Value of Listed Consumer Goods Companies in Nigeria. IOSR Journal of Business and Management, 23(2), 42-51. https://doi.org/10.9790/487X-2302074251

22. Vu, T. A. T., \& Le, V. H. (2021). The Effect of Tax Planning on Firm Value: A Case Study in Vietnam. Journal of Asian Finance, Economics and Business, 8(2), 973-979.

https://doi.org/10.13106/jafeb.2021.vol8.no2.0973 